\title{
Potential nursing effects of Parkia platycephala Benth. (Fabaceae) in a disturbed Brazilian Savanna area undergoing restoration
}

\author{
Efeitos potenciais da facilitação de Parkia platycephala Benth. (Fabaceae) em uma área
} antropizada da Savana brasileira em processo de recuperação

\author{
E. S. Cabral ${ }^{1}$; M. J. G. de Souza'2 R. J. de Oliveira²; R. R. Coimbra²; F. M. \\ Pelicice $^{2} ;$ W. de M. Ferreira ${ }^{2 *}$ \\ ${ }^{1}$ Instituto Federal de Educação, Ciência e Tecnologia do Maranhão, Campus de Açailândia, Rua Projetada, s/n, Vila \\ Progresso, 65930-000, Açailândia-Maranhão, Brazil \\ ${ }^{2}$ Núcleo de Estudos Ambientais, Universidade Federal do Tocantins, Rua 3, Quadra 17, Jardim dos Ipês, 77500-000 \\ Porto Nacional, Tocantins, Brazil \\ *wmelo@uft.edu.br \\ (Recebido em 21 de junho de 2021; aceito em 28 de dezembro de 2021)
}

\begin{abstract}
We evaluated the influence of Parkia platycephala on plant assemblages under its crown and surrounding areas in a disturbed Brazilian Savanna, as well as the effects of aqueous extracts of its leaves on the germination and development of three species, under the hypothesis that $P$. platycephala might work as a nurse species. Eleven areas of direct (ADIs) and indirect (AIIs) influence of P. platycephala and 11 control areas (COs) were delineated. All tree and shrub species present in these areas, including seedlings, were sampled. Richness, composition and abundance of woody taxa were determined. Laboratory studies analyzed the effects of $P$. platycephala aqueous leaf extracts on the germination and initial development of Dipteryx alata, Enterolobium gummiferum and Magonia pubescens, which in the field exhibited different abundance levels under its crown. Regarding plant assemblages, no differences in terms of richness and abundance of woody taxa were detected among the areas. However, we recorded a gradient of species composition and abundance ranks from ADI to $\mathrm{CO}$ areas. The number of seedlings also differed, with higher values near $P$. platycephala. Soil characteristics were similar among areas, but shading, plant height and diameter differed. The aqueous leaf extract at $25 \%$ provided the best germination of M. pubescens. The extract at $75 \%$ favored the initial development of this species in terms of root length. These results indicate that the presence of $P$. platycephala affects the structure of neighboring plant assemblages, possibly working as a facilitator for some species in areas undergoing restoration.
\end{abstract}

Keywords: Cerrado, facilitation, leaf extracts.

Avaliou-se a influência de Parkia platycephala na assembleia de plantas sob sua copa e áreas adjacentes numa área antropizada de Cerrado, bem como os efeitos de extratos aquosos de suas folhas na germinação e desenvolvimento de três espécies sob a hipótese de que P. platycephala pode provavelmente atuar como espécie facilitadora. Foram delimitadas 11 áreas de influência direta (AIDs) dessa espécie, 11 áreas de influência indireta (AIIs) e 11 áreas controle (COs). Todas as espécies lenhosas ocorrentes nessas áreas foram amostradas. A riqueza, composição e abundância dos táxons foram determinados. Os efeitos de extratos foliares de $P$. platycephala na germinação e desenvolvimento inicial de Dipteryx alata, Enterolobium gummiferum e Magonia pubescens, que exibiram diferentes níveis de abundância sob sua copa, também foram avaliados. Em relação à assembleia de plantas, não foram detectadas diferenças para riqueza e abundância dos táxons lenhosos entre as áreas. Entretanto, verificou-se um gradiente de composição de espécies e dos níveis de abundância das áreas AIDs para COs. O número de plântulas também diferiu, com valores mais altos próximo a $P$. platycephala. As características edáficas foram similares entre as áreas, mas o sombreamento, a altura e o diâmetro das plantas diferiram. A melhor germinação de $M$. pubescens foi obtida em $25 \%$ do extrato foliar, enquanto $75 \%$ favoreceu o desenvolvimento inicial dessa espécie em termos de comprimento radicial. Esses resultados indicam que a presença de $P$. platycephala afeta a estrutura das assembleias de plantas adjacentes, possivelmente funcionando como facilitadora para algumas espécies em áreas em processo de restauração.

Palavras-chave: Cerrado, facilitação, extratos foliares. 


\section{INTRODUCTION}

The Brazilian Savanna, locally known as "Cerrado", is a world hotspot for biodiversity conservation [1]. This complex vegetation domain, however, has been subjected to profound transformations over the last decades due to the expansion of human activities, particularly deforestation and land conversion to agriculture and cattle raising [2, 3]. According to Strassburg et al. (2017) [4], almost $46 \%$ of its native vegetation has been lost. Given this situation, ecological restoration turns out to be an essential alternative to mitigate or reverse some of the negative effects in disturbed areas [5]. Environmental restoration has become a common and necessary practice in Brazil, considering the present levels of disturbance caused by different acitivities such as urbanization, agriculture, fires, illegal exploitation and commercialization of wood, among other factors [6].

Ecological restoration by managing pionner species may constitute a successful strategy, because these species present rapid growth and are efficient in terms of water and nutrient use [7], providing adequate conditions for the establishment of secondary and climax species. For this reason, it is important to understand the role of certain pioneer and secondary species when introduced into natural environments. Among the various restoration techniques used is nucleation, a method that promotes facilitation by means of microhabitat formation. This technique has been proven to be efficient in fomenting the formation of stable, integrated communities $[8,9]$. Species that are able to promote these modifications have been denominated "foundation" and "nurse species" by Bruno et al. (2003) [10] and by Padilla and Pugnaire (2006) [11], respectively, because they provide conditions for the germination and growth of several other species. The planting of seedlings of target native species in disturbed sites is one of the techniques used to generate nucleus (nursing) effects capable of attracting greater biological diversity [8].

However, it is important to highlight that the presence of certain species can negatively affect the performance of neighboring plants in several ways. For example, pioneer species can act as strong competitors for resources or as inhibitors. Interspecific competition is one of the most common forms of interaction among plants, primarily during the process of community assembly, and quite often cause negative effects on diversity especially when there are dominant species [12]. Inhibitor species, in their turn, generally hinder the establishment of other species by competing for space and resources $[13,14]$, or by producing biochemicals that interfere in their germination or establishment (allelopathy) [15]. Studies carried out with tree species in the Cerrado savanna have demonstrated their inhibitory effects, but only in laboratory experiments where plant extracts (mostly from leaves) were used, whose phytotoxic activities were tested on the germination and growth of some species [16]. According to these authors, a number of scientists agree that such investigations (laboratorial) do not represent the natural conditions found in the ecosystem. Therefore, it is also important to evaluate, under field conditions, whether a species plays a positive, negative or neutral influence on the ability of a second species to invade and get established in a community [14].

In this study, we investigated community-level (assemblage structure) effects induced by a tree species commonly found in the Cerrado (Parkia platycephala Benth., Fabaceae), under the hypothesis that this tree works as a nurse species. In May 2006, 40 young individuals of $P$. platycephala were planted in a disturbed Cerrado area in the County of Porto Nacional, Tocantins, Brazil, so that the performance along their establishment in a natural environment could be evaluated. After planting the P. platycephala individuals in 2006, the area was abandoned, allowing natural colonization and dynamics, except for eventual domestic and wild animal grazing. The results revealed a high survival percentage and an outstanding growth capability of P. platycephala [17]. Moreover, this species has the largest crown among those planted in 2006. These traits (survival, growth and shading) suggest that $P$. platycephala may facilitate the establishment of other species, accelerating the restoration of disturbed areas [18, 19]. In light of the above, this study evaluated the influence of $P$. platycephala on plant assemblages under its crown and surrounding areas in a disturbed Brazilian savanna Cerrado undergoing a process of natural restoration. 
We also investigated organism-level (seed germination and initial growth) effects induced by $P$. platycephala on other native species, under the hypothesis that this tree may affect the development of the neighboring plants. Although we have not found any evidence of allelopathic effects related to $P$. platycephala in the literature, a few studies have shown that other species of the genus Parkia such as P. speciosa [20], P. clappertoniana [21], P. biglobosa [22] and P. pedula [23] synthesize flavonoids, triterpenes, steroids and esters which have been associated with allelopathic activities. Thus, it is possible that these compounds are also present in the leaves of $P$. platycephala and exert some kind of influence on the germination and development of certain species under or near its crown. For this reason, under this hypothesis, a companion laboratory experiment tested the effects of $P$. platycephala aqueous leaf extracts on the germination and initial development of Dipteryx alata, Enterolobium gummiferum and Magonia pubescens, species that exhibited different abundance levels under the crowns of $P$. platycephala.

\section{MATERIAL AND METHODS}

\subsection{Study area and target species}

The study was carried out in a cerrado sensu stricto area at Fazenda São Judas Tadeu $\left(10^{\circ} 48^{\prime} 31^{\prime \prime} \mathrm{S}\right.$ and $\left.48^{\circ} 26^{\prime} 52^{\prime \prime} \mathrm{W}\right)$ situated in the County of Porto Nacional, Tocantins, Brazil. The area is considered disturbed because it was used for animal grazing prior to the beginning of the study in 2006 [17]. The soil of the area is Concretionary and has medium texture [24].

Parkia platycephala Benth., our target species, is a member of the Fabaceae family and is popularly known as "sabiú", "fava de bolota", or "badoqueiro". It is a native species distributed throughout the Brazilian North, Northeast and Central-west regions [25], found in areas of Cerrado, Caatinga and the Amazon Rainforest [25, 26]. According to MMA (2007) [18] and Sano et al. (2008) [19], this tree species could act as a facilitator species in the process of restoration of different ecosystems. It is a tree species of rapid growth, reaching from 8 to 18 meters in height, has a broad crown with decumbent branches which often touch the ground. In reforestation programs, its crown favors the development of late secondary species [27]. As stated by Bulhão and Figueiredo (2002) [28], P. platycephala is a facultative evergreen species and leaf abscission occurs late in the dry season after fruit production. It is economically important, e.g., timber industry, forage for ruminants and ornamental potential [27, 29]. Because it is a common plant throughout the State of Tocantins, it is recognized as the State tree [30].

\subsection{Community-level effects}

To investigate the effects of $P$. platycephala on plant assemblage structure, the study considered a gradient of its influence: (i) under $P$. patycephala crowns (direct influence), (ii) areas adjacent to its crowns (indirect influence), and (iii) areas free of its influence (absence of $P$. platycephala).

Out of the 40 individuals of $P$. platycephala planted in 2006 (for more information see Alves et al. 2016 [17]), 11 were selected for the present study. The selection considered that each $P$. platycephala individual was isolated from one another, with no overlapping crowns. The mean distance between individuals was 27.2 meters. For each individual, we delineated areas of direct influence (ADI) and areas of indirect influence (AII). The ADI corresponded to the horizontal crown projection of each individual on the ground as defined by two perpendicular axes whose radii were measured from the center of the tree trunk (Figure 1). The AII was defined on the basis of each radius of the ADI (the same values), projected immediately outside the crown. Eleven control areas (CO) were also delineated at least 30 meters away from any P. platycephala individual. The mean crown diameter, trunk diameter and height of the individuals were $11.8 \mathrm{~m}$, $12.3 \mathrm{~cm}$ and $3.8 \mathrm{~m}$, respectively. The size of the control areas was standardized as the average sizes of both ADI and AII combined, assuming these areas were in the shape of an ellipse. No $P$. platycephala individual was present in the control areas. We considered each area an independent 
sampling unity, totaling 11 samples/treatment and 33 samples in all. The three areas are relatively close to each other, so they were subjected to the same climate regime (humid tropical classified as Aw, according to Köppen [31], which is characterized by rainy Summers and dry Winters), environmental conditions and disturbance (animal grazing). Species were also classified according to their functional dispersion syndromes based on bibliographical research.

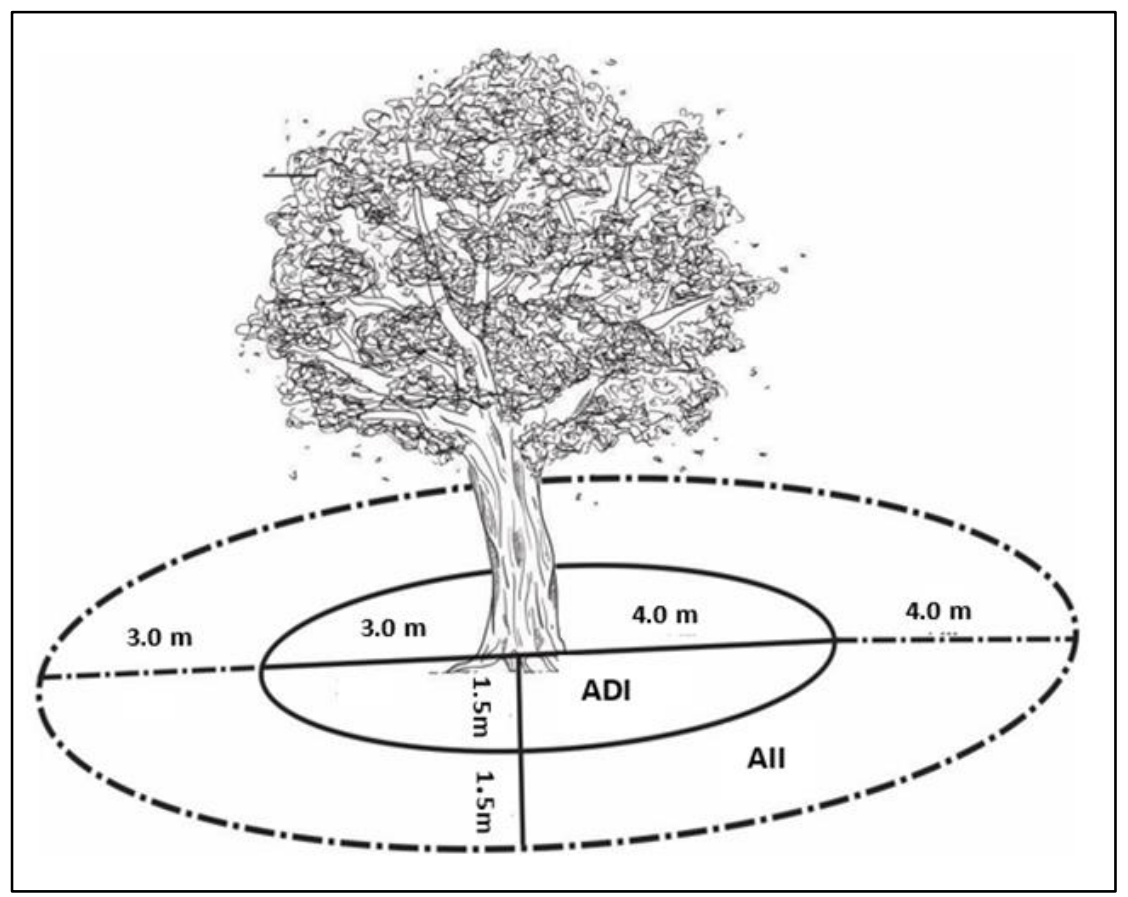

Figure 1: Schematic diagram of the areas of direct (ADI) and indirect (AII) influence of Parkia platycephala as calculated in the present study.

Data were collected from February to August 2016, ten years after the planting of $P$. platycephala individuals in the study area. All $P$. platycephala specimens selected for the study as well as the control areas were georeferenced. All woody specimens (including seedlings) in the three areas (ADI, AII and CO) were identified and measured for height $(\mathrm{m})$ and diameter at ground level (mm). Most seedling species were identified in the field. When this was not possible, they were carefully removed with their roots and taken to the Tocantins Herbarium (HTO) for identification. Only seedlings of woody species were included in the analyses. Resprouts were considered adult individuals. Shading percentage was determined by randomly measuring the amount of light available one meter above ground level (three readings in each area) in relation to full sun, by means of a digital light meter (General Tools DLM2, New Jersey, USA). Readings were recorded on days with no clouds during the month of June. In order to compare soil chemical and physical properties ( $\mathrm{pH}$, macronutrient, aluminum and organic matter contents, and texture), we collected four samples (at 0-20 cm depth) per P. platycephala individual (two from the ADI and two from the AII) and four samples from each control area. These samples were analyzed in the Soil Analysis Laboratory of the Federal Institute of Tocantins.

\subsection{Effects of $\boldsymbol{P}$. platycephala leaf extracts on germination and seedling development}

Laboratory experiments were conducted to investigate the effects of aqueous extracts of $P$. platycephala leaves on the germination and initial development of other Cerrado plant species. Three species were selected for these experiments: Dipteryx alata Vog. (Fabaceae), Enterolobium gummiferum (Mart.) J. F. Macbr. (Fabaceae) and Magonia pubescens St. Hil. (Sapindaceae). Selection was based on their relative abundance under P. platycephala crowns (ADI) according to the species abundance rank (Figue 5): low (D. alata ranked $23^{\text {rd }}$ ), intermediate (E. gummiferum 
ranked $9^{\text {th }}$ ) and high abundance (M. pubescens ranked $2^{\text {nd }}$ ). In addition, this selection was based on seed availability at the time of the experiments.

The extracts were prepared according to Gatti et al. (2004) [32] and Grisi et al. (2011) [33]. Young and adult leaves of $P$. platycephala were collected from five individuals. They were washed in running water for approximately five minutes for debris removal and then dried for 96 hours in an oven set to $45^{\circ} \mathrm{C}$. Following that, the leaves were ground in a knife-type mill (Marconi - MA 340, São Paulo, Brazil). An aqueous extract was obtained using deionized water as the solvent, and a crude extract (100 g of dry leaves in $1 \mathrm{~L}$ of deionized water) was prepared. This crude extract was kept at $5^{\circ} \mathrm{C}$ for one hour and then vacuum-filtered through one layer of filter paper to obtain the most concentrated extract (100\%). From this extract, three dilutions were made using deionized water, resulting in the following concentrations: $75 \%, 50 \%$ and $25 \%$. We evaluated the effects of these extract concentrations in addition to pure deionized water (control treatment) on the germination and initial development of the three species mentioned above.

A completely randomized experimental design was carried out. For $D$. alata and $E$. gummiferum there were five repetitions, each consisting of 10 seeds laid on double-layer filter paper disks placed in 11-cm glass Petri dishes $(\mathrm{n}=50)$. For M. pubescens, whose seeds are much larger, there were 10 repetitions, each consisting of 5 seeds $(n=50)$. The Petri dishes (containing the filter paper disks) were autoclaved at $120^{\circ} \mathrm{C}$ and $105 \mathrm{kPa}$ for 15 minutes before the addition of $25 \mathrm{~mL}$ of the extracts, and then followed by seed sowing. Prior to sowing, seeds were surface sterilized with $50 \%$ (v/v) commercial bleach (2.5\% active chlorine) in deionized/autoclaved water solution for 15 minutes, followed by two 15-minute rinses in deionized/autoclaved water. The Petri dishes containing the seeds were kept in a growth room at $27 \pm 1^{\circ} \mathrm{C}$ under a 16-hour photoperiod provided by cool-white fluorescent lamps (Empalux, Brazil) at $30-35 \mu \mathrm{mol} \mathrm{m}^{-2} \mathrm{~s}^{-1}$ (measured by a digital light meter - General Tools DLM2, New Jersey, USA). Five days after the beginning of the experiment, $15 \mathrm{~mL}$ of the extracts were added to each Petri dish.

\subsection{Statistical analyses}

To examine community-level effects, we investigated woody plant assemblage structure in the three areas (ADI, AII and CO) considering variations in plant density (individuals $/ \mathrm{m}^{2}$ ), species density (species $/ \mathrm{m}^{2}$ ), total richness and composition of woody taxa. To investigate patterns in total richness, we calculated rarefaction curves (95\% confidence intervals) based on the number of individuals sampled [34]. For this analysis, we considered only taxa identified to the genus or species levels (excluding morpho-species). We applied non-parametric Anova (Kruskal-Wallis) to investigate differences in individual (abundance) and species densities, average height, average diameter and shading percentage among areas. The Dunn's test was applied to verify differences among means. We applied the same protocol to investigate variation in the physical and chemical characteristics of the soil.

Variations in assemblage composition (based on taxon densities) were investigated using four different analyses. First, non-metric multidimensional scaling (NMDS) was applied to graphically depict variations in assemblage composition, based on Bray-Curtis distance. Second, significant differences in composition were tested with one-way Analysis of Similarity (ANOSIM), considering treatments (areas) as groups. Third, a Similarity Percentage (SIMPER) analysis was applied to partition the relative contribution of each species to the overall dissimilarity observed among treatments. Finally, we compared variations in taxon abundance ranks (relative abundance, $\%$ ). For this, we considered species that summed $90 \%$ of the abundance in the ADI areas (all samples pooled), and then plotted their abundances for the three areas.

To evaluate the effect of the extracts on seed germination, the following variables were used: germination percentage and mean germination rate, according to Ranal et al. (2009) [35]. Seeds were considered germinated when $2-3 \mathrm{~mm}$ of the radicle was visible. Germinated seedlings were transferred to individual plastic pots $(7 \mathrm{~cm}$ height $\times 6 \mathrm{~cm}$ basal diameter) containing a 4:1 mix of Cerrado soil (collected from CO areas) and Bioplant (Minas Gerais, Brazil). Initial development was analyzed by assessing plant height, number of leaves, stem diameter, longest root length, and shoot and root dry matter 30 days after transferring seedlings to the pots. At the moment of transfer 
and at 10-day intervals, seedlings were irrigated with $15 \mathrm{~mL}$ of the extracts. They were irrigated daily with tap water until the substrate reached the saturation point. Differences in germination and development among treatments were evaluated by the analysis of variance (one-way ANOVA, and the means were compared by the Tukey test at the 5\% probability level. Percentage results were arcsine transformed to normalize variation. The experiments were repeated twice. The results represent the average of the two repetitions.

The statistical analyses in both community and organism-level experiments were carried out in Sisvar 5.6 [36] and PAST 1.75b [34]. Statistical significance implied $P<0.05$.

\section{RESULTS AND DISCUSSION}

\subsection{Community-level effects}

Overall, 1,540 individuals of 108 woody species and 34 plant families were sampled in the study area. Seventy-six taxa were identified to the species level, while the remaining were identified to the genus, family or morphospecies levels. Many individuals at seedling stage could not be identified. In the ADI areas, we recorded 237 individuals, 56 species and 23 families; in the AII, 639 individuals, 79 species and 29 families; in the CO, 664 individuals, 67 species and 26 families (Table 1). The most predominant families were Fabaceae (18 species - 16.5\%), Myrtaceae (9 species - 8.3\%), Malpighiaceae ( 8 species $-7.3 \%$ ), Bignoniaceae ( 7 species $-6.4 \%$ ) and Apocynaceae (6 species - 5.5\%). Thirty-one species (28.70\%) were common to the three treatment areas. Ten species $(9.25 \%)$ were observed only in the ADI areas. Twenty species $(18.51 \%)$ were present only in AII, while $18(16.67 \%)$ were exclusive to the CO areas.

Table 1: Species, their respective abundance and dispersal syndromes recorded in areas under the influence of Parkia platycephala and in control areas in a cerrado sensu stricto in Porto Nacional, Tocantins, Brazil. ADI = areas under direct influence; $A I I=$ areas under indirect influence; $C O=$ control areas (P. platycephala absent), DS = dispersal syndrome; $A N E=$ anemochoric; $Z O O=$ zoochoric; $A U T=$ autochoric; $I N D=$ indeterminate.

\begin{tabular}{|c|c|c|c|c|c|}
\hline Families & Species & DS & ADI & AII & $\mathrm{CO}$ \\
\hline \multirow[t]{4}{*}{ Anacardiaceae } & Anacardium occidentale L. & $\mathrm{ZOO}$ & 1 & 6 & 6 \\
\hline & Anacardium sp. & $\mathrm{ZOO}$ & & 1 & 2 \\
\hline & Astronium fraxinifolium Schott & ANE & & 3 & 9 \\
\hline & Myracrodruon urundeuva Allemão & ANE & & 1 & \\
\hline \multirow[t]{4}{*}{ Annonaceae } & Annona coriacea Mart. & $\mathrm{ZOO}$ & 4 & 3 & 2 \\
\hline & Annona sp. & $\mathrm{ZOO}$ & 2 & & 13 \\
\hline & Annona sylvatica A. St.-Hil. & $\mathrm{ZOO}$ & 1 & 1 & \\
\hline & Xylopia aromatica (Lam.) Mart. & $\mathrm{ZOO}$ & & 4 & 2 \\
\hline \multirow[t]{6}{*}{ Apocynaceae } & Aspidosperma macrocarpon Mart. & ANE & & 13 & 4 \\
\hline & Aspidosperma nobile Müll. Arg. & ANE & & & 6 \\
\hline & Aspidosperma sp. & ANE & & 1 & \\
\hline & Aspidosperma tomentosum Mart. & ANE & 4 & 4 & 2 \\
\hline & Hancornia speciosa Gomes & $\mathrm{ZOO}$ & 1 & 3 & \\
\hline & Himatanthus obovatus (Müll. Arg.) Woodson & ANE & 2 & 12 & 3 \\
\hline Arecaceae & Syagrus sp. & $\mathrm{ZOO}$ & & & 1 \\
\hline Asteraceae & Tilesia baccata (L. f.) Pruski & $\mathrm{ZOO}$ & 6 & 1 & \\
\hline \multirow{7}{*}{ Bignoniaceae } & Anemopaegma arvense (Vell.) Stellfeldex de Souza & ANE & 2 & 2 & \\
\hline & Cybistax antisyphilitica (Mart.) Mart. & ANE & 1 & & \\
\hline & Fridericia $\mathrm{sp.}$ & ANE & & 1 & \\
\hline & Handroanthus ochraceus (Cham.) Mattos & ANE & 1 & 7 & 16 \\
\hline & Handroanthus serratifolius (Vahl) S. Grose & ANE & 1 & 1 & \\
\hline & Jacaranda brasiliana (Lam.) Pers. & ANE & & 2 & \\
\hline & Tabebuia aurea (Silva Manso) Benth. \& Hook. f. ex S. Moore & ANE & 4 & 8 & 3 \\
\hline Bixaceae & Cochlos permumregium (Mart. exSchrank) Pilg. & ANE & & 1 & \\
\hline Calophyllaceae & Kielmeyera coriacea Mart. \&Zucc. & ANE & 1 & 1 & 5 \\
\hline Caryocaraceae & Caryocar brasiliense Cambess. & $\mathrm{ZOO}$ & & 7 & 17 \\
\hline
\end{tabular}




\begin{tabular}{|c|c|c|c|c|c|}
\hline Families & Species & DS & ADI & AII & CO \\
\hline \multirow[t]{3}{*}{ Celastraceae } & Peritassa campestris (Cambess.) A. C. Sm. & $\mathrm{ZOO}$ & 9 & 8 & 31 \\
\hline & Salacia elliptica (Mart. exSchult.) G. Don & $\mathrm{ZOO}$ & & 1 & \\
\hline & Salacia sp. & $\mathrm{ZOO}$ & 1 & 2 & 1 \\
\hline Chrysobalanaceae & Couepia grandiflora (Mart. \&Zucc.) Benth. & $\mathrm{ZOO}$ & 1 & & 10 \\
\hline \multirow[t]{2}{*}{ Connaraceae } & Connarus suberosus Planch. & $\mathrm{ZOO}$ & 3 & 12 & 19 \\
\hline & Rourea induta Planch. & $\mathrm{ZOO}$ & 11 & 32 & 46 \\
\hline \multirow[t]{2}{*}{ Dilleniaceae } & Curatella americana $\mathrm{L}$. & $\mathrm{ZOO}$ & 3 & 11 & 5 \\
\hline & Davilla ellipticaA. St.-Hil. & $\mathrm{ZOO}$ & & & 1 \\
\hline Ebenaceae & Diospyros hispida A. DC. & $\mathrm{ZOO}$ & 14 & 23 & 53 \\
\hline \multirow[t]{2}{*}{ Erythroxylaceae } & Erythroxylum sp. & $\mathrm{ZOO}$ & & 1 & 9 \\
\hline & Erythroxylum suberosum A. St.-Hil. & $\mathrm{ZOO}$ & 4 & 18 & 32 \\
\hline \multirow[t]{18}{*}{ Fabaceae } & Andira cujabensis Benth. & $\mathrm{ZOO}$ & 5 & 7 & 19 \\
\hline & Andira sp. & $\mathrm{ZOO}$ & & 1 & 1 \\
\hline & Bauhinia acuruana Moric. & AUT & 27 & 70 & 4 \\
\hline & Bauhinia sp. & AUT & 1 & 3 & \\
\hline & Bowdichia virgilioides Kunth & ANE & & & 1 \\
\hline & Cenostigma macrophyllum Tul. & AUT & 5 & 30 & 56 \\
\hline & Dipteryx alata Vogel & $\mathrm{ZOO}$ & 3 & 3 & \\
\hline & Enterolobium gummiferum (Mart.) J. F. Macbr. & AUT/ZOO & 8 & 5 & \\
\hline & Galactia glaucescensKunth & AUT & & & 3 \\
\hline & Hymenaea stigonocarpa Mart. exHayne & $\mathrm{ZOO}$ & 1 & 1 & 1 \\
\hline & Inga laurina $(\mathrm{Sw}$.$) Willd.$ & $\mathrm{ZOO}$ & 1 & & \\
\hline & Leptolobium dasycarpum Vogel & ANE & 1 & & \\
\hline & Plathymenia reticulata Benth. & ANE & & 5 & 8 \\
\hline & Pterodon emarginatus Vogel & ANE & 1 & 7 & 13 \\
\hline & Stryphnodendron adstringens (Mart.) Coville & AUT/ZOO & 12 & 78 & 9 \\
\hline & Tachigali aurea Tul. & ANE & 5 & 6 & 1 \\
\hline & Tachigali vulgaris L. G. Silva \& H. C. Lima & ANE & & & 1 \\
\hline & Vatairea macrocarpa (Benth.) Ducke & ANE & & 5 & 25 \\
\hline Hypericaceae & Vismia guianensis (Aubl.) Choisy & $\mathrm{ZOO}$ & 1 & 15 & \\
\hline Lamiaceae & Aegiphila verticillataVell. & $\mathrm{ZOO}$ & & 1 & \\
\hline \multirow[t]{2}{*}{ Lythraceae } & Lafoensia pacari A. St.-Hil. & ANE & 3 & 18 & 9 \\
\hline & Physocalym mascaberrimum Pohl & ANE & & & 1 \\
\hline \multirow[t]{8}{*}{ Malpighiaceae } & Banisteriopsis sp. & ANE & & 1 & \\
\hline & Byrsonima crassifolia (L.) Kunt & $\mathrm{ZOO}$ & & 2 & 2 \\
\hline & Byrsonima pachyphylla A. Juss. & $\mathrm{ZOO}$ & & 1 & 3 \\
\hline & Byrsonima sp. & $\mathrm{ZOO}$ & & 1 & \\
\hline & Byrsonima verbascifolia (L.) DC. & $\mathrm{ZOO}$ & 1 & 1 & 4 \\
\hline & Heteropterys byrsonimifolia A. Juss. & ANE & 3 & 13 & \\
\hline & Heteropterys sp. & ANE & & & 12 \\
\hline & Malpighiaceae sp & - & & & 1 \\
\hline \multirow[t]{2}{*}{ Malvaceae } & Eriotheca gracilipes (K.Schum.) A. Robyns & ANE & 1 & 2 & 4 \\
\hline & Pseudobombax tomentosum (Mart. \&Zucc.) A. Robyns & ANE & & & 1 \\
\hline \multirow[t]{2}{*}{ Melastomataceae } & Miconia albicans (Sw.) Triana & $\mathrm{ZOO}$ & & & 1 \\
\hline & Mouriri pusa Gardner & $\mathrm{ZOO}$ & & 2 & 3 \\
\hline Moraceae & Brosimum gaudichaudii Trécul & $\mathrm{ZOO}$ & & 1 & \\
\hline \multirow[t]{9}{*}{ Myrtaceae } & Eugenia dysenterica (Mart.) DC. & $\mathrm{ZOO}$ & & & 1 \\
\hline & Myrcia multiflora (Lam.) DC. & $\mathrm{ZOO}$ & 2 & 2 & 8 \\
\hline & Myrcia sp1 & $\mathrm{ZOO}$ & 8 & 10 & 4 \\
\hline & Myrcia sp2 & $\mathrm{ZOO}$ & 1 & 1 & 1 \\
\hline & Myrcia splendens (Sw.) DC. & $\mathrm{ZOO}$ & & 3 & 21 \\
\hline & Psidium myrtoides O. Berg & $\mathrm{ZOO}$ & 10 & 27 & 7 \\
\hline & Psidium sp. & $\mathrm{ZOO}$ & & 5 & \\
\hline & Myrtaceae sp1 & - & 1 & & \\
\hline & Myrtaceae sp2 & - & & & 2 \\
\hline Ochnaceae & Ouratea spectabilis (Mart.) Engl. & $\mathrm{ZOO}$ & & 6 & 10 \\
\hline \multirow[t]{2}{*}{ Rubiaceae } & Cordiera sessilis (Vell.) Kuntze & $\mathrm{ZOO}$ & & & 1 \\
\hline & Tocoyena formosa (Cham. \&Schltdl.) K. Schum. & $\mathrm{ZOO}$ & 8 & 10 & 18 \\
\hline Salicaceae & Casearia sylvestris $\mathrm{Sw}$ & $\mathrm{ZOO}$ & 10 & 15 & 17 \\
\hline Sapindaceae & Magonia pubescens A. St.-Hil. & ANE & 15 & 30 & 8 \\
\hline
\end{tabular}




\begin{tabular}{|c|c|c|c|c|c|}
\hline Families & Species & DS & ADI & AII & $\mathrm{CO}$ \\
\hline Sapotaceae & Pouteria ramiflora (Mart.) Radlk. & $\mathrm{ZOO}$ & & 10 & 21 \\
\hline Simaroubaceae & Simarouba versicolor A. St.-Hil. & $\mathrm{ZOO}$ & & & 2 \\
\hline \multirow[t]{3}{*}{ Solanaceae } & Solanum lycocarpum A. St.-Hil. & $\mathrm{ZOO}$ & & 1 & \\
\hline & Solanum paniculatum $\mathrm{L}$. & $\mathrm{ZOO}$ & & 4 & \\
\hline & Solanum sp. & $\mathrm{ZOO}$ & & 1 & \\
\hline Vitaceae & Cissus campestris (Baker) Planch. & $\mathrm{ZOO}$ & 1 & & \\
\hline Vochysiaceae & Qualea grandiflora Mart. & ANE & & & 2 \\
\hline \multirow[t]{13}{*}{ Undetermined 1} & Morphospecies 1 & & & 1 & \\
\hline & Morphospecies 2 & & & 1 & \\
\hline & Morphospecies 3 & & 2 & & \\
\hline & Morphospecies 4 & & 1 & 1 & \\
\hline & Morphospecies 5 & & & 2 & \\
\hline & Morphospecies 6 & & 2 & 1 & \\
\hline & Morphospecies 7 & & & 1 & \\
\hline & Morphospecies 8 & & 1 & & \\
\hline & Morphospecies 9 & & 1 & & \\
\hline & Morphospecies 10 & & 7 & & \\
\hline & Morphospecies 11 & & 4 & & \\
\hline & Morphospecies 12 & & & 2 & \\
\hline & Morphospecies 13 & & & 3 & \\
\hline \multirow[t]{2}{*}{ Undetermined 2} & Morphospecies 14 & & & & 1 \\
\hline & Morphospecies 15 & & & & 1 \\
\hline Total & & & 237 & 639 & 664 \\
\hline
\end{tabular}

ADI areas totaled $200.59 \mathrm{~m}^{2}$ (mean 18.24), AII totaled $601.76 \mathrm{~m}^{2}$ (mean 54.71) and CO $660 \mathrm{~m}^{2}$ (mean 60.00). Rarefaction curves showed similar behaviors, with a weak indication of more species in AII and CO, considering the $95 \%$ confidence intervals (Figure 2). We also observed no difference in plant abundance and species densities among treatment areas (Table 2). These results suggest that the presence of $P$. platycephala does not affect the number of species and plant abundance in local assemblages, which indicate co-existence between this tree species and other plants living under its crowns and adjacent areas.

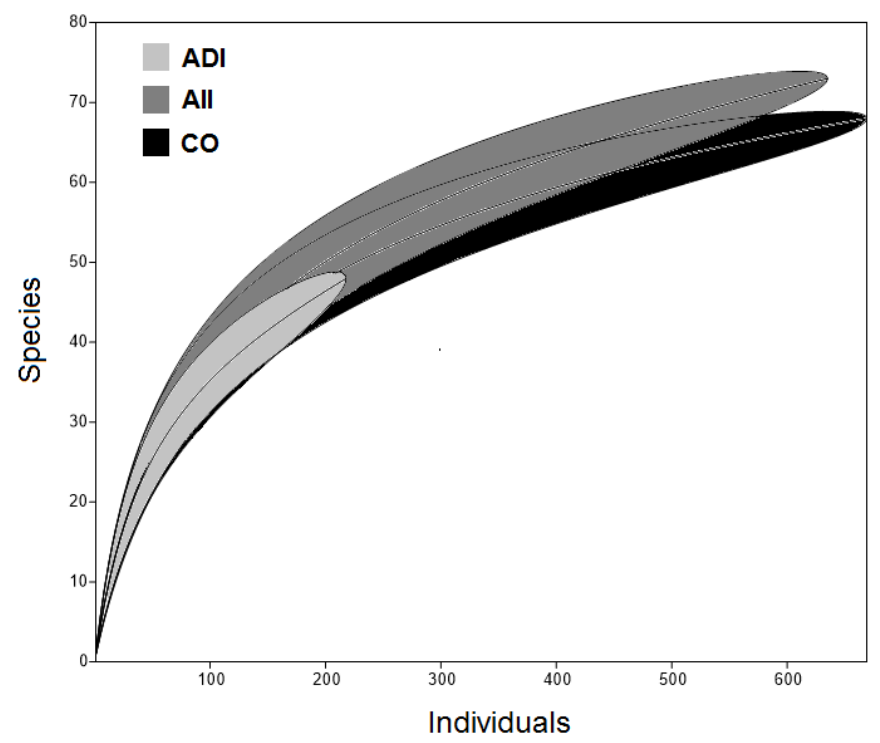

Figure 2: Species rarefaction curves (95\% confidence intervals) controlling for sampling effort (individuals) of plants recorded in areas under the influence of Parkia platycephala and in control areas in a cerrado sensu stricto in Porto Nacional, Tocantins, Brazil. Curves were calculated separately for each area. $A D I=$ areas under direct influence of $\mathrm{P}$. platycephala; $A I I=$ areas under indirect influence; $\mathrm{CO}=$ control areas (P. platycephala absent $)$. 
The floristic composition and vegetation structure on local scales may be associated, among other factors, with physicochemical properties of the soil [37,38]. The edaphic characteristics (Table 2) showed that soil of the three areas are medium-textured and acidic ( $\mathrm{pH} 4.3$ to 4.6). Phosphorous levels were very low in all areas; $\mathrm{K}$ values were considered moderate, and $\mathrm{Ca}, \mathrm{Mg}$ and base saturation were considered low in all areas. Organic matter was medium at ADI and within an adequate range at AII and CO. CTC was within adequate limits in all areas [39]. In general, soil analyses revealed that the areas were similar in terms of macronutrients and soil texture, indicating that edaphic conditions did not vary substantially among the areas. Although other studies in Cerrado areas have demonstrated that soil physical and chemical traits affect floristic composition $[38,40]$, the present study indicated that edaphic properties possibly played a minor role in determining differences in plant diversity among areas directly and indirectly influenced by $P$. platycephala and control areas.

Table 2: Plant assemblage attributes and soil characteristics in areas under the influence of Parkia platycephala and in control areas in a cerrado sensu stricto in Porto Nacional, Tocantins, Brazil. ADI = areas under direct influence; $A I I=$ areas under indirect influence; $C O=$ control areas $(\mathrm{P}$. platycephala absent). Differences among areas (bold letters) were tested with non-parametric Anova (Kruskal-Wallis), complemented with Dunn's test at the 5\% probability level. Values followed by the same letters (lines) are not significantly different.

\begin{tabular}{|c|c|c|c|c|c|c|c|}
\hline & \multicolumn{2}{|c|}{ ADI } & \multicolumn{2}{|c|}{ AII } & \multicolumn{2}{|c|}{$\mathrm{CO}$} & \multirow{2}{*}{$\begin{array}{c}\text { K- } \\
\text { Wallis } \\
\text { p-value }\end{array}$} \\
\hline & $\mathbf{X}$ & SD & $\mathbf{X}$ & SD & $\mathbf{X}$ & SD & \\
\hline \multicolumn{8}{|l|}{ Assemblage attributes } \\
\hline Species density (species. $\mathrm{m}^{-2}$ ) & 0.820 & 0.515 & 0.573 & 0.328 & 0.357 & 0.093 & 0.075 \\
\hline Abundance (individual. $\mathrm{m}^{-2}$ ) & 1.452 & 1.030 & 1.427 & 0.891 & 1.006 & 0.494 & 0.438 \\
\hline Average height $(\mathrm{m})$ & $0.710^{\mathrm{a}}$ & 0.314 & $0.915^{\mathrm{a}}$ & 0.224 & $1.335^{\mathbf{b}}$ & 0.202 & 0.001 \\
\hline Average diameter (mm) & $2.164^{\mathrm{a}}$ & 1.747 & $2.128^{\mathrm{a}}$ & 0.408 & $3.124^{\mathbf{b}}$ & 0.548 & 0.002 \\
\hline Shading percentage & $83.31^{\mathrm{a}}$ & 8.911 & $77.27^{\mathbf{a b}}$ & 7.539 & $63.44^{\mathbf{b}}$ & 9.122 & 0.0002 \\
\hline Seedling density (plant. $\mathrm{m}^{-2}$ ) & $0.527^{\mathrm{a}}$ & 0.513 & $0.396^{\mathbf{a}}$ & 0.201 & $0.138^{\mathbf{b}}$ & 0.183 & 0.010 \\
\hline Seedling relative abundance $(\%)$ & $31.95^{\mathrm{a}}$ & 20.95 & $29.41^{\mathbf{a}}$ & 5.38 & $11.73^{\mathbf{b}}$ & 8.61 & 0.003 \\
\hline \multicolumn{8}{|l|}{ Soil chemical and physical properties } \\
\hline $\mathrm{pH}$ in $\mathrm{H}_{2} \mathrm{O}$ & 4.582 & 0.354 & 4.364 & 0.223 & 4.654 & 0.464 & 0.113 \\
\hline Phosphorous (P) (mg. dm ${ }^{-3}$ ) & 1.800 & 0.577 & 2.360 & 0.980 & 2.000 & 1.177 & 0.346 \\
\hline Potassium $(\mathrm{K})\left(\mathrm{mg} \cdot \mathrm{dm}^{-3}\right)$ & 30.636 & 9.403 & 27.727 & 8.624 & 41.818 & 17.403 & 0.086 \\
\hline Calcium $(\mathrm{Ca})\left(\mathrm{cmol}_{\mathrm{c}} \mathrm{dm}^{-3}\right)$ & 0.282 & 0.072 & 0.336 & 0.098 & 0.736 & 1.263 & 0.388 \\
\hline Magnesium $(\mathrm{Mg})\left(\mathrm{cmol}_{\mathrm{c} . \mathrm{dm}^{-3}}\right)$ & 0.300 & 0.060 & 0.264 & 0.098 & 0.309 & 0.254 & 0.508 \\
\hline Aluminum $(\mathrm{Al})\left(\mathrm{cmol}_{c} \mathrm{dm}^{-3}\right)$ & 0.682 & 0.204 & 0.754 & 0.227 & 0.591 & 0.254 & 0.334 \\
\hline Potential acidity $(\mathrm{H}+\mathrm{Al})\left(\mathrm{cmol}_{\mathrm{cdm}}{ }^{-3}\right)$ & 3.768 & 1.285 & 3.625 & 0.739 & 4.036 & 1.117 & 0.709 \\
\hline Cation Exchange Capacity (T) $\left(\mathrm{cmol}_{c} \mathrm{dm}^{-3}\right)$ & 4.424 & 1.333 & 4.294 & 0.778 & 5.186 & 1.780 & 0.589 \\
\hline Base saturation $(\%)$ & 15.816 & 3.833 & 15.921 & 3.803 & 18.864 & 14.647 & 0.907 \\
\hline Organic matter $(\%)$ & 1.841 & 0.365 & 2.232 & 0.822 & 2.475 & 0.724 & 0.098 \\
\hline Sand $(\%)$ & 63.456 & 5.325 & 63.628 & 6.424 & 62.096 & 4.273 & 0.800 \\
\hline Clay $(\%)$ & 25.454 & 4.498 & 27.394 & 4.598 & 27.2700 & 4.176 & 0.385 \\
\hline Silt $(\%)$ & 11.092 & 3.724 & 8.892 & 2.773 & 10.635 & 3.487 & 0.336 \\
\hline
\end{tabular}

However, we detected significant differences in shading percentage, plant height and diameter among the three areas (Table 2). Shading was higher in ADI and AII compared to CO, and no significant difference existed between the first two areas, or between AII and CO. Regarding plant height and diameter, plants sampled in $\mathrm{CO}$ areas exhibited greater values when compared with those sampled in both ADI and AII. These differences may result in specific environmental conditions in areas under the influence of $P$. platycephala, especially related to the shading regime. According to Zanine and Santos (2004) [41], aspects related to the crown, such as height and thickness, may dictate coexistence patterns in plant assemblages. The shading regime may act as a limiting factor for the development of some trees and shrubs under or near $P$. platycephala, especially if they require higher light availability. On the other hand, it may 
facilitate the establishment of plants that are more tolerant or even demand shaded environments $[42,43]$, as required by intermediate and climax species. According to Vásquez-Yánes and Orozco-Segovia (1994) [44], the amount of available light directly affects plant biomass, and light quality controls physiological processes, promoting or inhibiting germination, flowering, stem growth and leaf expansion and orientation. Although light quality was not evaluated, $P$. platycephala probably influences the light regime and its properties, affecting the germination and growth of other species.

Plant composition differed among areas. The ordination (NMDS, stress value $=0.27$ ) tended to group CO samples (Figure 3), with high within-group dissimilarity in areas under the influence of $P$. platycephala (ADI and AII). Similarly, ANOSIM indicated that CO differed significantly from other groups $(\mathrm{R}=0.25 ; P<0.0001)$ and SIMPER analysis showed high dissimilarity among groups (average dissimilarity $=82.49$ ). This latter analysis also showed that, among the species that most contributed to overall dissimilarity, the majority tended to decline from ADI to CO areas. These results indicate that assemblage composition is particular and more heterogeneous in areas under the influence of $P$. platycephala, with a gradient of taxon composition and densities between ADI and CO. Shading provided by crowns of $P$. platycephala can explain these patterns, considering that this tree forms broad, but not so dense crowns. Passos et al. (2014) [5] reported that facilitator species such as Solanum lycocarpum enhance environmental heterogeneity under their crowns due to partial shading, which can provide favorable conditions for species with different light requirements. In addition, they showed that this species also worked in a nucleation process.

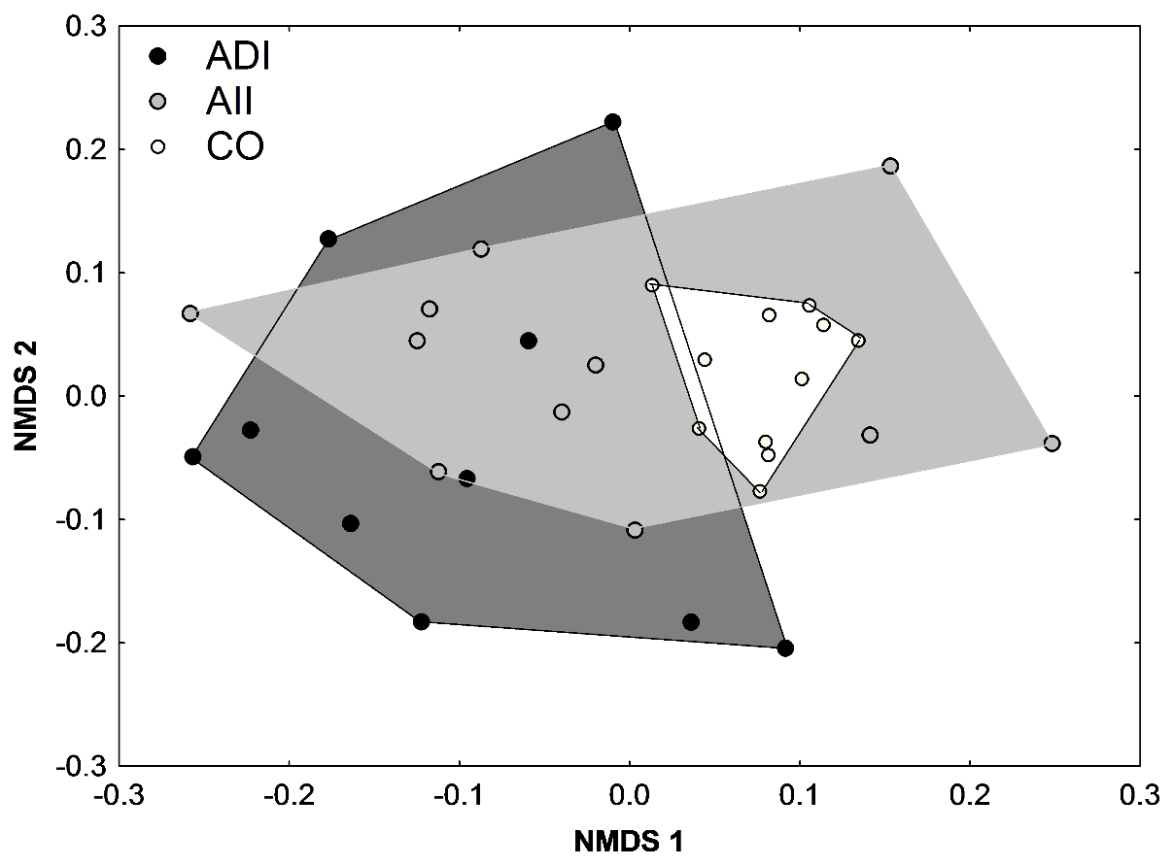

Figure 3: Non-Metric Multidimensional Scaling (NMDS) showing variation in plant assemblage structure (abundance and composition; Bray-Curtis distance) in areas under the influence of Parkia platycephala and in control areas in a cerrado sensu stricto in Porto Nacional, Tocantins, Brazil. ADI = areas under direct influence; $A I I=$ areas under indirect influence; $C O=$ control areas $(\mathrm{P}$. platycephala absent).

Considering that soil characteristics were similar among areas, it is likely that differences and variation in the shading regime create dynamic environmental filters, including light and soil moisture. Another aspect that might have influenced the observed results may possibly be related to seed dispersal by arboreal animals or birds that could be using the nurse trees as perches. Seed banks might also have affected the obtained outcome. Most woody species studied by Kuhlmann and Ribeiro (2016) [45] in the Cerrado exhibited zoochoric dispersal syndrome. These authors included Myrtaceae in the list of the most representative families recorded in their study, and this 
family was the second most predominant in the present study. Anderson and Pinto (1985) [46] reported that gum exudates from $P$. bicolor and $P$. biglobosa, and gum from the seed pods of $P$. pendula, may be related to mechanisms of seed dispersal associated with the genus Parkia. Although we have not collected or analyzed gum exudates from $P$. platycephala in our study, this species most likely serves as perches for birds or attracts other arboreal animals, as mentioned above, who aid seed dispersal. Indeed $62.2 \%$ of the species exhibit zoochoric dispersal (Table $1)$.

Abundance ranks (considering taxa that summed $90 \%$ of total abundance in the ADI treatment, $\mathrm{S}=28$ taxa) showed contrasting distributions between areas under the influence of $P$. platycephala and the control treatment (Figure 4). For example, rank distributions were roughly similar between ADI and AII areas, and most taxa recorded in ADI were also recorded in AII (27 shared). Differently, the most abundant taxa in CO ranked $12^{\text {th }}$ (Qualea parviflora) and $15^{\text {th }}$ (Cenostigma macrophyllum) at ADI, and only 23 out of 28 taxa were recorded in $\mathrm{CO}$ areas (summing 62\% of total abundance). The five main species at ADI (Bauhinia acuruana, Magonia pubescens, Diospyros hispida, Stryphnodendron adstringens and Rourea induta) totaled $36 \%$ of total abundance in ADI and AII, but only $18 \%$ in CO areas. Therefore, these results indicate environmental effects of $P$. platycephala on the structure of local assemblages, supporting the existence of a gradient of composition and abundance from ADI to CO areas.

Seedling abundance differed among areas. We recorded 369 seedlings, distributed as follows: 95 in the ADI, 183 in the AII and 91 in the CO. Seedling density and relative abundance showed higher values under the crowns of $P$. platycephala and adjacent areas (Table 2), indicating a possible nursing effect. This target species is a large tree with broad crowns (a characteristic that is not so common among tree species in cerrado sensu stricto areas), that provides specific abiotic conditions (i.e., shading), probably favoring seed germination and establishment of shade-tolerant species. Moreover, seed dispersers (e.g., birds) are regularly observed visiting $P$. platycephala. It would increase propagule pressure in the neighboring areas, maintaining the rhythm of secondary and late succession [8]. Therefore, the combined effect of shading and dispersal may explain the higher abundance of seedlings around $P$. platycephala.

\subsection{Effects of $P$. platycephala leaf extracts on germination and initial development}

The results regarding the influence of aqueous extracts of $P$. platycephala leaves on the germination and initial development of Magonia pubescens, Enterolobium gummiferum and Dipteryx alata are shown on Table 3. We verified that germination of M. pubescens was greatest at 25\% (but not significantly different from the control treatment) and decreased at higher concentrations. At this concentration, germination percentage and mean germination rate were superior to and significantly higher $(P<0.05)$ than the control treatment, respectively, although germination did not differ significantly from the control treatment. Both variables were inhibited at higher extract concentrations. No significant differences were detected for the germination of E. gummiferum among the treatments, although mean germination increased at $25 \%$ of the crude extract and decreased at higher concentrations. Similar results were obtained for $D$. alata except for the fact that the germination percentage was significantly inhibited by the crude extract. In general, the results obtained showed that the extracts did not exert a strong influence on the germination of D. alata and E. gummiferum. Souza Filho et al. (2005) [23] reported that the secondary metabolites (two phenolic compounds and a terpenoid) produced by Parkia pendula exhibited low inhibitory potential on the germination of Mimosa pudica and Senna obtusifolia seeds, both also members of the Fabaceae family. In relation to M. pubescens, however, the germination rate was significantly higher at $25 \%$, indicating a significant positive effect. It is possible that during the rainy season, rainwater washes the leaves of $P$. platycephala and carries some leaf compounds (at very low concentrations) to the soil, which positively influence the germination of $M$. pubescens. It is worth noting that $M$. pubescens showed a strong gradient of abundance in the field study, ranking $2^{\text {nd }}$ in the ADI, $5^{\text {th }}$ in the AII and $25^{\text {th }}$ in the control areas. 

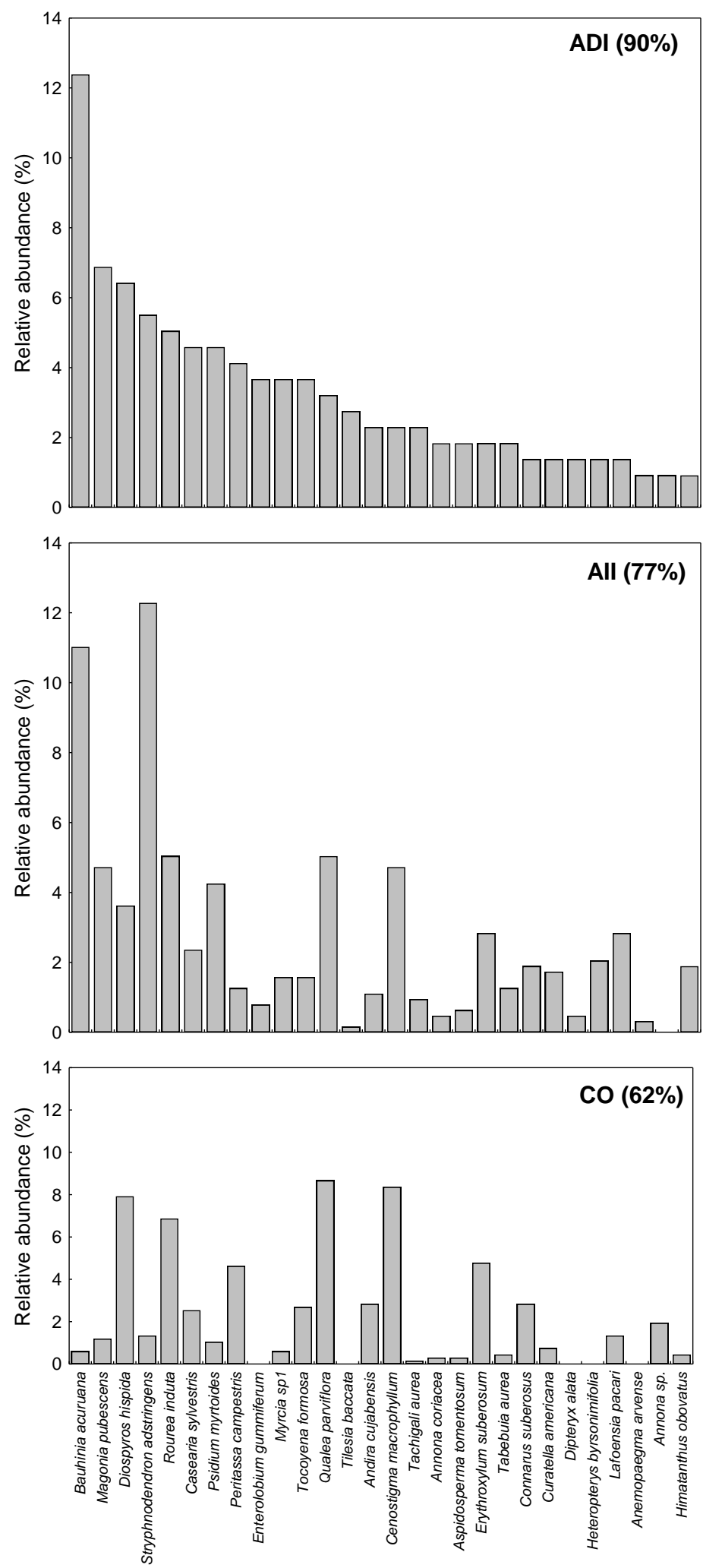

Figure 4: Abundance ranks of plant taxa recorded in areas under the influence of Parkia platycephala and in control areas in a cerrado sensu stricto in Porto Nacional, Tocantins, Brazil. We plotted taxa that totaled $90 \%$ of total abundance in the ADI treatment. ADI = areas under direct influence; AII = areas under indirect influence; $C O=$ control areas (P. platycephala absent). (\%) Percentage contribution of these taxa to total abundance in each area. 
Table 3: Effects of different concentrations of aqueous extracts of Parkia platycephala leaves on the germination and initial growth of Dipteryx alata, Enterolobium gummiferum and Magonia pubescens. $G$ = germination percentage; $M G M=$ mean germination rate; $P H=$ plant height $; D=$ stem diameter; $L R L=$ longest root length; $A D M=$ plant aerial dry matter; $R D M=$ root dry matter. Values followed by the same letter (lines) are not significantly different according to the Tukey's test at the 5\% probability level.

\begin{tabular}{|c|c|c|c|c|c|}
\hline Variables & Control $\left(\mathrm{H}_{2} \mathbf{O}\right)$ & $25 \%$ & $\mathbf{5 0 \%}$ & $75 \%$ & $100 \%$ \\
\hline \multicolumn{6}{|c|}{ Dipteryx alata } \\
\hline $\mathrm{G}(\%)$ & $93.3 \mathrm{a}$ & $91.1 \mathrm{a}$ & $93.3 \mathrm{a}$ & $82.2 \mathrm{a}$ & $66.6 \mathrm{~b}$ \\
\hline $\operatorname{MGR}\left(\right.$ seeds day $\left.{ }^{-1}\right)$ & $0.151 \mathrm{a}$ & $0.162 \mathrm{a}$ & $0.142 \mathrm{a}$ & $0.139 \mathrm{a}$ & $0.138 \mathrm{a}$ \\
\hline $\mathrm{PH}(\mathrm{cm})$ & $7.87 \mathrm{a}$ & $9.11 \mathrm{a}$ & $10.07 \mathrm{a}$ & $10.11 \mathrm{a}$ & $6.71 \mathrm{~b}$ \\
\hline $\mathrm{SD}(\mathrm{mm})$ & $2.65 \mathrm{a}$ & $2.93 \mathrm{a}$ & $2.94 \mathrm{a}$ & $3.03 \mathrm{a}$ & $2.72 \mathrm{a}$ \\
\hline $\mathrm{LRL}(\mathrm{cm})$ & $13.02 \mathrm{a}$ & $11.81 \mathrm{a}$ & $12.49 \mathrm{a}$ & $11.86 \mathrm{a}$ & $9.98 \mathrm{a}$ \\
\hline $\operatorname{ADM}(\mathrm{g})$ & $0.433 \mathrm{a}$ & $0.447 \mathrm{a}$ & $0.593 \mathrm{a}$ & $0.632 \mathrm{a}$ & $0.398 \mathrm{a}$ \\
\hline RDM (g) & $0.087 \mathrm{a}$ & $0.103 \mathrm{a}$ & $0.116 \mathrm{a}$ & $0.099 \mathrm{a}$ & $0.079 \mathrm{a}$ \\
\hline \multicolumn{6}{|c|}{ Enterolobium gummiferum } \\
\hline $\mathrm{G}(\%)$ & $100 \mathrm{a}$ & $98.3 \mathrm{a}$ & $95.0 \mathrm{a}$ & $96.65 \mathrm{a}$ & $93.3 \mathrm{a}$ \\
\hline MGR (seeds hour-1) & $0.02 \mathrm{a}$ & $0.035 \mathrm{a}$ & $0.021 \mathrm{a}$ & $0.016 \mathrm{a}$ & $0.015 \mathrm{a}$ \\
\hline $\mathrm{PH}(\mathrm{cm})$ & $5.62 \mathrm{a}$ & $7.00 \mathrm{a}$ & $6.76 \mathrm{a}$ & $6.63 \mathrm{a}$ & $5.90 \mathrm{a}$ \\
\hline $\mathrm{SD}(\mathrm{mm})$ & $2.16 \mathrm{a}$ & $2.17 \mathrm{a}$ & $2.19 \mathrm{a}$ & $2.02 \mathrm{a}$ & $2.16 \mathrm{a}$ \\
\hline LRL (cm) & $7.74 \mathrm{a}$ & $7.95 \mathrm{a}$ & $5.56 \mathrm{a}$ & $6.00 \mathrm{a}$ & $5.15 \mathrm{a}$ \\
\hline $\operatorname{ADM}(\mathrm{g})$ & $0.197 \mathrm{a}$ & $0.166 \mathrm{a}$ & $0.177 \mathrm{a}$ & $0.175 \mathrm{a}$ & $0.164 \mathrm{a}$ \\
\hline RDM (g) & $0.012 \mathrm{a}$ & $0.013 \mathrm{a}$ & $0.012 \mathrm{a}$ & $0.012 \mathrm{a}$ & $0.012 \mathrm{a}$ \\
\hline \multicolumn{6}{|c|}{ Magonia pubescens } \\
\hline $\mathrm{G}(\%)$ & $84.0 \mathrm{a}$ & $94.0 \mathrm{a}$ & $74.0 \mathrm{ab}$ & $70 \mathrm{ab}$ & $57.5 \mathrm{~b}$ \\
\hline MGR (seeds day ${ }^{-1}$ ) & $0.203 \mathrm{~b}$ & $0.260 \mathrm{a}$ & $0.197 \mathrm{~b}$ & $0.200 \mathrm{~b}$ & $0.172 \mathrm{~b}$ \\
\hline $\mathrm{PH}(\mathrm{cm})$ & $9.20 \mathrm{a}$ & $9.81 \mathrm{a}$ & $11.34 \mathrm{a}$ & $10.08 \mathrm{a}$ & $10.23 \mathrm{a}$ \\
\hline $\mathrm{SD}(\mathrm{mm})$ & $2.37 \mathrm{a}$ & $2.28 \mathrm{a}$ & $2.14 \mathrm{a}$ & $2.17 \mathrm{a}$ & $2.22 \mathrm{a}$ \\
\hline $\mathrm{LRL}(\mathrm{cm})$ & $10.60 \mathrm{~b}$ & $12.9 \mathrm{ab}$ & $12.94 \mathrm{ab}$ & $15.20 \mathrm{a}$ & $12.22 \mathrm{ab}$ \\
\hline $\mathrm{ADM}(\mathrm{g})$ & $2.389 \mathrm{a}$ & $2.281 \mathrm{a}$ & $2.304 \mathrm{a}$ & $2.306 \mathrm{a}$ & $2.540 \mathrm{a}$ \\
\hline RDM (g) & $0.160 \mathrm{a}$ & $0.155 \mathrm{a}$ & $0.130 \mathrm{a}$ & $0.153 \mathrm{a}$ & $0.152 \mathrm{a}$ \\
\hline
\end{tabular}

Extracts at $75 \%$ significantly favored the initial development of $M$. pubescens seedlings in terms of root length (Table 3). This is evidence that this concentration was beneficial to root growth in length, probably by favoring cell division and extension [47]. Similar results were reported by Rosa et al. (2011) [48] and Martinelli and Silva (2018) [49] upon studying the effects of leaf extracts of Panicum maximum on the radicle length of Peltophorum dubium seedlings, and the influence of aqueous extracts of Secale cereale on the growth of Beta vulgaris roots, respectively. No marked influence was observed in terms of stem diameter and dry matter buildup in roots. For E. gummiferum, at $25 \%$ of the extract plants were $21.6 \%$ higher than the control treatment. No pronounced effects were detected for the other variables although the concentrations of 25 and $50 \%$ generally provided higher values, except for aerial dry matter. All variables assessed in $D$. alata, apart from root length, were positively influenced by the extracts (50 and 75\% concentrations). A possible explanation for the stimulus of seedling growth in height, as observed in the three species, can be related to the action of the extract on their endogenous hormonal production [50], which in this case could be primarily associated with an increase in the synthesis of gibberellins. This group of hormones is known to stimulate extension of cells of plant stems [51, 52].

Taken together, these results point to the trend that the extracts at low and moderate concentrations $(25-75 \%$ of the crude extracts) exhibited a tendency to favor germination percentage of $M$. pubescens as well as growth and development of the species assessed. In fact, the $25 \%$ concentration aqueous extract increased the germination rate of all three species. This is a possible indication, as mentioned above, that rainwater containing trace amounts of certain leaf 
compounds might favor seed germination and promote the development of these species, thus contributing to the observed abundance in areas under direct and indirect influence of $P$. platycephala in the field experiment. Magonia pubescens and E. gummiferum were ranked second and fifth in terms of abundance in the areas under direct and indirect influence of $P$. platycephala, respectively. Ferreira and Aquila (2000) [53] stated that plants synthesize secondary metabolites and that these compounds can promote or inhibit physiological processes of other species, depending on their sensitivity. It is also important to mention that E. gummiferum and D. alata were not present in the control areas, which probably suggest that other than shading, they might have benefitted from some chemical cue associated with the presence of $P$. platycephala. Another aspect that deserves to be raised is the fact that several Parkia species are nitrogen fixers $(54,55)$. Although we have not found specific information related to P. platycephala we believe it can be included in this group of Parkia species. This characteristic enhances the development of neighboring species facilitating their development $[56,57]$.

\section{CONCLUSIONS}

This study provided evidence that the presence of Parkia platycephala affects the structure of neighboring plant assemblages, possibly working as a nurse for some species in the area. We recorded a gradient of species composition and abundance ranks from the areas of direct influence (ADI) to the control (CO) areas, with a higher abundance of seedlings near P. platycephala, indicating a possible nursing role for some species. Considering that soil characteristics were similar among areas, it is likely that differences and variation in the shading regime provided by $P$. platycephala created heterogeneous conditions and dynamic environmental filters. These factors must affect the establishment of other plants, especially shade-tolerant species. Because this tree grows rapidly (in height and diameter) and is resistant and resilient to disturbances, it likely plays a role during initial phases of succession, serving as a nurse species. It is important to emphasize that these findings refer to a 10-year period after the experimental establishment of $P$. platycephala in the area. Further studies addressing, for example, direct seeding and/or manipulated plant introductions at ADI and AII, as well as the effects on the water-holding capacity of the soil, should help unveil additional details regarding its role in the plant community under its crown and in surrounding areas.

The laboratory experiment that investigated the effects of aqueous extracts of $P$. platycephala leaves provided support that this tree possibly affects other species via chemical compounds. It revealed that the extracts favored the germination of $M$. pubescens at intermediate concentrations but exerted negative effect on D. alata and E. gummiferum at the highest concentration. These results point to the possibility that, in the natural environment, rainwater leaches certain compounds from leaf tissues (at much lower concentrations when compared to the extracts used in the present study) and reaches the soil near the crowns of $P$. platycephala, aiding seed germination and the development of some species. Future studies aiming to test the effect of leaf extracts on other Cerrado species, as well as to identify the chemical nature of such compounds will certainly shed more light on our present findings.

\section{ACKNOWLEDGEMENTS}

The authors thank Mr. Sebastião Vitorino Rodrigues, owner of Fazenda São Judas Tadeu, for kindly allowing us to use part of the area of his farm to carry out this research and for providing logistic support whenever we needed. Fernando Pelicice received a research grant from CNPq (Conselho Nacional de Desenvolvimento Científico e Tecnológico). This research did not receive any specific grant from funding agencies in the public, commercial, or not-for-profit sectors. We thank the reviewers who provided valuable comments and corrections. 


\section{REFERENCES}

1. Myers N, Mittermeier RA, Mittermeier CG, Fonseca GAB, Kent J. Biodiversity hotspots for conservation priorities. Nature. 2000 Feb;403:853-858. doi: 10.1038/35002501

2. Klink CA, Machado RBA. Conservação do Cerrado brasileiro. Megadiversidade. 2005 Jul;1(1):147-55.

3. Ferreira RQS, Camargo MO, Teixeira PR, Souza PB, Viana RHO. Uso potencial e síndromes de dispersão das espécies de três áreas de Cerrado sensu stricto, Tocantins. Gl Sci Technol. 2016 SepDec;9(3):73-86.

4. Strassburg BBN, Brook T, Feltran-Barbieri R, Iribarrem A, Crouzeilles R, Loyola R, et al. Moment of truth for the Cerrado hotspot. Nat Ecol Evol. 2017 Mar;1(4):1-3. doi: 10.1038/s41559-017-0099

5. Passos FB, Lopes CM, Ribeiro FGA. Nurse plant effect of Solanum lycocarpum A. St.-Hil in area of Brazilian Savanna undergoing a process of restoration. Braz J Bot. 2014;37(3):251-9. doi: 10.1007/s40415-014-0079-9

6. Lahsen M, Bustamante MMC, Dalla-Nora EL. Undervaluing and overexploiting the Brazilian Cerrado at our peril. Sci Policy Sust Develop. 2016 Nov;58(6):4-15. doi: 10.1080/00139157.2016.1229537

7. Santos Junior UM, Gonçalves JFC, Feldpausch TR. Growth, leaf nutrient concentration and photosynthetic nutrient use efficciency in tropical tree species planted in degraded areas in central Amazonia. For Ecol Manag. 2006 May;226(3):299-309. doi: 10.1016/j.foreco.2006.01.042

8. Reis A, Bechara FC, Espíndola MB, Vieira NK, Souza LL. Restauração de áreas degradadas: a nucleação como base para incrementar os processos sucessionais. Nat Conserv. 2003 Apr;1(1):28-36.

9. Bechara FC, Campos Filho EM, Barretto KD, Gabriel VA, Antunes AZ, Reis A. Unidades demonstrativas de restauração ecológica através de técnicas nucleadoras de biodiversidade. Rev Bras de Biocienc. 2007 Jul;5(1):9-11.

10. Bruno JF, Stachowicz JJ, Bertness MD. Inclusion of facilitation into ecological theory. Trends Ecol Evol. 2003 Mar;18(3):119-125. doi: 10.1016/S0169-5347(02)00045-9

11. Padilla FM, Pugnaire FI. The role of nurse plants in the restoration of degraded environments. Front Ecol Environ. 2006 May;4(4):196-202. doi: 10.1890/1540-9295(2006)004[0196:TRONPI]2.0.CO;2

12. Bengtsson J, Fagerstram T, Rydin H. Competition and coexistence in plant communities. Trends Ecol Evol. 1994 Jul;9(7):246-50. doi: 10.1016/0169-5347(94)90289-5

13. Connell JH, Slatyer RO. Mechanisms of succession in natural communities and their role in community stability and organization. Am Nat. 1977 Nov-Dec;111(982):1119-44.

14. Ricklefs R, Relyea R. A economia da natureza. 7. ed. Rio de Janeiro: Editora Guanabara Koogan; 2016.

15. Mota JAX, Lemos HAF, Ferreira WN, Silva MAM. Allelopathic effect of Azadirachta indica fresh leaves on the germination of native plants in the Seasonally Dry Tropical Forest. Scientia Plena. 2020;16(12):12402. doi: 10.14808/sci.plena.2020.124202

16. Novaes P, Molinillo JMG, Varela RM, Macías FA. Ecological phytochemistry of Cerrado (Brazilian savanna) plants. Phytochem Ver. 2013 Aug;12(4):839-55. doi: 10.1007/s11101-013-9315-3

17. Alves LR, Oliveira RJ, Coimbra RR, Ferreira WM. Crescimento inicial de Parkia platycephala (Benth.) e Enterolobium timbouva (Mart.) sob condições de campo numa área de Cerrado. Rev Ceres. 2016 MarApr;63(2):154-64. doi: 10.1590/0034-737X201663020006

18. Ministério do Meio Ambiente (MMA). Biodiversidade do Cerrado e Pantanal. Áreas e ações prioritárias para conservação. Brasília (DF): Editora MMA; 2007.

19. Sano SM, Almeida SP, Ribeiro JF. Cerrado: ecologia e flora. Planaltina (DF): Editora Embrapa; 2008.

20. Jamaluddin F, Mohamed S, Lajis MN. Hypoglycaemic effect of stigmast-4-en-3-one from Parkia speciosa empty pods. Food Chem. 1995;54(1):9-13. doi: 10.1016/0308-8146(95)92656-5

21. Lemmich E, Adewunmi CO, Furu P, Kristensen A, Larsen L, Olsen CE. 5-Deoxyflavona from Parkia clappertoniana. Phytochemistry. 1996 Jul;42(4):1011-3. doi: 10.1016/0031-9422(96)00101-X

22. Tringali C, Spatafora C, Longo OD. Bioactive constituents of the bark of Parkia biglobosa. Fitoterapia. 2000 Apr;71(2):118-25. doi: 10.1016/s0367-326x(99)00137-9

23. Souza Filho APS, Fonseca ML, Arruda MSP. Substâncias químicas com atividades alelopáticas presentes nas folhas de Parkia pendula (Leguminosae). Planta Daninha 2005 Dec;23(4):565-73. doi: 10.1590/S0100-83582005000400002

24. Secretaria do Planejamento e Meio Ambiente do Estado do Tocantins (Seplan). Atlas do Tocantins: subsídios ao planejamento da gestão territorial [Internet]; 2005 [cited 2020 Oct 05]. Available from: https://central.to.gov.br/download/213445

25. Forzza RC, Baumgratz JFA, Costa A, Hopkins M, Leitman PM, Lohmann LG, et al. As Angiospermas do Brasil. In: Forzza RC, Baumgratz JFA, Bicudo CEM, et al. Catálogo de plantas e fungos do Brasil. Rio de Janeiro: Editora do Instituto de Pesquisas Jardim Botânico do Rio de Janeiro; 2010. p. 78-89. 
26. Oliveira LC, Hopkins M. Parkia in Flora do Brasil 2020 em construção. Jardim Botânico do Rio de Janeiro [Internet]; 2020 [cited 2020 Jul 23]. Available from: http://floradobrasil.jbrj.gov.br/reflora/floradobrasil/FB83548

27. Pereira MS. Manual técnico conhecendo e produzindo sementes e mudas da Caatinga. Fortaleza (CE): Editora Associação Caatinga; 2011.

28. Bulhão CF, Figueiredo PS. Fenologia de leguminosas arbóreas em uma área de cerrado marginal no Maranhão. Rev Bras Bot. 2002 Sep;25(3):361-9. doi: 10.1590/S0100-84042002000300012

29. Lorenzi, H. Árvores brasileiras. Manual de identificação e cultivo de plantas arbóreas do Brasil. 2. ed. Nova Odessa (SP): Instituto Plantarum; 1998.

30. Estado do Tocantins. Poder Legislativo do Estado do Tocantins. Lei no 2.619 , de 09 de agosto de 2012. Define os símbolos da natureza do Estado do Tocantins, e adota outras providências. Diário Oficial do Estado do Tocantins. 13 ago 2012;3691:1-2. Available from: https://central3.to.gov.br/arquivo/345125/

31. Alvares CA, Stape JL, Sentelhas PC, Gonçalves, JLM, Sparovek G. Köppen's climate classification map for Brazil. Meteorol Z. 2013 Dec;22(6):711-28. doi: 10.1127/0941-2948/2013/0507

32. Gatti, AB, Perez SCJGA, Lima MIS. Atividade alelopática de extratos aquosos de Aristolochia esperanzae O. Kuntze na germinação e no crescimento de Lactuca sativa L. e Raphanus sativus L. Acta Bot Bras. 2004 Sep;18(3):459-72. doi: 10.1590/S0102-33062004000300006

33. Grisi AB, Gualtieri SCJ, Ranal MA, Santana DG. Efeito alelopático do fruto de Sapindus saponaria na germinação e na morfologia de plântulas daninhas e de hortaliças. Planta Daninha. 2011 Jun;29(2):31122. doi: 10.1590/S0100-83582011000200009

34. Hammer O, Harper DAT, Ryan PD. Past: Paleontologia Statistics software package for education and data analysis. Paleontol Electronica. 2001 Jun;4(1):1-9.

35. Ranal MA, Santada DG, Ferreira WR, Rodrigues CM. Calculating germination measurements and organizing spreadsheets. Rev Bras Bot. 2009 Oct-Dec;32(4):849-55. doi: 10.1590/S010084042009000400022

36. Ferreira DF. Sisvar: a computer statistical analysis system. Cien Agrotec. 2011 Dec;35(6):1039-42. doi: 10.1590/S1413-70542011000600001

37. Ribeiro JF, Walter BMT. As principais fitofisionomias do Bioma Cerrado. In: Sano SM, Almeida SP, Ribeiro JF, editors. Cerrado: ecologia e flora. Planaltina (DF): Editora Embrapa; 2008. p. 151-212.

38. Neri AV, Schaefer CEGR, Silva AF, Souza AL, Ferreira Junior WG, Meira Neto JAA. The influence of soils on the floristic composition and community structure of an area of Brazilian Cerrado vegetation. Edinb J Bot. 2012 Feb;69(1):1-27. doi: 10.1017/S0960428611000382

39. Sousa DMG, Lobato E. Cerrado: correção do solo e adubação. 2. ed. Planaltina (DF): Editora Embrapa; 2004.

40. Abreu MF, Pinto JRR, Maracahipes L, Gomes L, Oliveira EA, Marimon BS, et al. Influence of edaphic variables on the floristic composition and structure of the tree-shrub vegetation in typical and rocky outcrop cerrado areas in Serra Negra, Goiás State, Brazil. Braz J Bot. 2012;35(3):259-72.

41.Zanine ADM, Santos EM. Competição entre espécies de plantas - uma revisão. Rev FZVA. 2004;11(1):10-30.

42. Freitas GA, Vaz-de-Melo A, Pereira MAB, Andrade CAO, Lucena GN, Silva RR. Influência do sombreamento na qualidade de mudas de Sclerolobium paniculatum Vogel para recuperação de área degradada. J Biotec Biodivers. 2012 Aug;3(3):5-12. doi: 10.20873/jbb.uft.cemaf.v3n3.freitas

43. Reis SM, Morandi PS, Oliveira B, Oliveira EA, Valadão MBX, Marimon BS, et al. Influência do sombreamento no desenvolvimento inicial e eficiência no uso de nutrientes de Dilodendron bipinnatum Radkl (Sapindaceae). Sci For. 2015 Sep;43(107):581-90.

44. Vásquez-Yánes C, Orozco-Segovia A. Signals for seeds to sense and respond to gaps. In: Caldwell M, Pearcy RW, editors. Exploitation of environment heterogeneity by plants. Ecophysiological processes above-and belowground. San Diego (CA): Editora Academic Press; 1994. p. 209-36 Available from: https://www.sciencedirect.com/science/article/pii/B9780121550707500123

45. Kuhlmann M, Ribeiro JF. Evolution of seed dispersal in the Cerrado biome: ecological and phylogenetic considerations. Acta Bot Bras. 2016 Apr-Jun;30(2):271-82. doi: 10.1590/0102-33062015abb0331

46. Anderson DMW, Pinto GL. Gum polysaccharides from three Parkia species. Phytochemistry. 1985;24(1):77-9. doi: 10.1016/S0031-9422(00)80810-9

47. Ferreira EGBS, Matos VP, Sena LHM, Sales GFA. Efeito alelopático do extrato aquoso de sabiá na germinação de sementes de fava. Rev Ciênc Agron. 2010 Jul-Sep;41(3):463-7.

48. Rosa DM, Fortes AMT, Mauli MM, Marques DS, Palma D. Potencial alelopático de Panicum maximum Jacq. sobre a germinação de sementes de espécies nativas. Floram. 2011 Apr-Jun;18(2):198-203. doi: 10.4322/floram.2011.038

49. Martinelli VA, Silva VN. Efeito alelopático de centeio na germinação e crescimento de plântulas de beterraba. Agrarian Academy. 2018 Jul;5(9):195-203. doi: 10.18677/Agrarian_Academy_2018a20 
50. Rice EL. Allelopathy. New York: Academic Press; 1984.

51. Almeida AQ, Vieira EL. Efeito da giberelina líquida no crescimento e desenvolvimento do fumo tipo Sumatra. Rev FZVA. 2010;16(2):204-19.

52. Mouco MAC, Ono EO, Rodrigues JD. Inibidores de síntese de giberelinas e crescimento de mudas de mangueira 'Tommy Atkins'. Cienc Rural. 2010 Feb; 40(2):273-279. doi: 10.1590/S010384782010000200004

53. Ferreira AG, Aquila MEA. Alelopatia: uma área emergente da ecofisiologia. R Bras Fisiol Veg. 2000;12(Edição Especial):175-204.

54. Halliday J. Integrated approach to nitrogen fixing tree germplasm development. Pesq Agropec Bras. 1984 Jun;19:91-117.

55. Singh, MK. Potential of underutilized legume tree Parkia timoriana (DC.) Merr. In Eco-restoration of Jhum fallows of Manipur. J Pharmacogn Phytochem. 2019 Mar-Apr;8(2):1685-7.

56. Bellingham PJ, Walker LR, Wardle DA. Differential facilitation by a nitrogen-fixing shrub during primary succession influences relative performance of canopy tree species. J Ecol. 2002 Mar; 89:86175. doi: 10.1046/j.0022-0477.2001.00604.x

57. Olsen SL, Sandvik SM, Totland Orjan. Influence of two n-fixing legumes on plant community properties and soil nutrient levels in an alpine ecosystem. Arct Antarct Alp Res. 2013 May;45(3):36371. doi: $10.1657 / 1938-4246-45.3 .363$ 